\title{
Cranial nerve block after test dose through an epidural catheter in a pre- eclamptic parturient
}

A case of unintentional high spinal anaesthesia is reported, in a 40-year-ald obese patient at 38 weeks gestation, complicated by pre-eciampsia. In spite of careful technique in placement of an epidurai catheter, the test dose of 3 ml bupivacaine 0.5 per cent produced an unusual block which ascended to include sensory blockade of the fifth cranial nerve, but the motor components of the cervical and thoracic segments were spared. This case suggests that a smaller epidural test dose of bispivacaine might be appropriate, especially in an obese and pre-eclamptic parturient.

\section{Key words}

ANAESTHETIC TECHNIQUES: epidural; $\Lambda$ NAESTHETICS: local, bupivacaine; COMPLICATIONS: total spinal anaesthetic.

Total spinal anaesthesia is a well known complication of an unintentional overdose of a local anaesthetic in the subarachnoid space. ${ }^{1.2}$ The use of a test dose through an epidural catheter is intended to prevent such an untoward complication. ${ }^{3}$ This report describes an unusual case of high spinal anaesthesia involving the cranial nerves from a test dose of local anaesthetic injected into the epidural catheter in a pre-eclamptic parturient.

\section{Case report}

A forty-four-year-old, $104 \mathrm{~kg}, 5^{\prime} 2^{\prime \prime}$ woman at 38

From the Department of Ancsthesiology, University of Utah School of Medicine, Salt Lake City, Utah.

Address correspondence 10: Dr. K.C. Wong, Department of Anesthesiology, 50 North Medical Drive, Salt Lake City, Utah, USA. 84132. weeks gestation was admitted for induction of labour because of persistently elevated blood pressures, $1^{+}$proteinuria and mild generalized oedema of one week duration, despite bed rest. She was receiving no medical treatment, although she had a history of chronic hypertension with resting blood pressures in the range of $130-150 / 80-90 \mathrm{mmHg}$ and this had been treated with oral hydralazine prior to this pregnancy. No discernable labour pattern developed after a 48 -hour trial of oxytocin infusion, thus Caesarean-section was scheduled.

Review of systems was negative for visual disturbance, headache, abdominal pain, or dyspnoea. Physical exam revealed an obese female not in active labour and in no distress. Blood pressures during her 48 -hour hospital stay were in the $170-180 / 90-104 \mathrm{mmHg}$ range; pulse 90 and regular; respiration 20 and unlabourcd. Hcart and lung examinations were unremarkable. There was mild generalized oedema and deep tendon reflexes were within normal limits.

A peripheral venous catheter was established, with maintenance IV fluids given; urine output was approximately $100 \mathrm{ml}$ per hour. Laboratory findings: sodium $139 \mathrm{mEq} / \mathrm{L}$, potassium $4.1 \mathrm{mEq} / \mathrm{L}$, chloride $108 \mathrm{mEq} / \mathrm{L}, \mathrm{CO}_{2} 19 \mathrm{mEq} / \mathrm{L}$; glucose 99 $\mathrm{mg} / \mathrm{dl}$, BUN $8 \mathrm{mg} / \mathrm{dl}$, albumin $3.9 \mathrm{~g}$ per cent, fibrinogen $620 \mathrm{mg} / \mathrm{d}$, haematocrit 35.5 per cent, platelets 235,000 , creatinine $1.0 \mathrm{mg} / \mathrm{dl}$; urinalysis revealed a specific gravity of 1.022 with a trace of protein, total urine protein $250 \mathrm{mg}$ per liter per 24 hours.

In preparation for lumbar epidural anaesthesia, a central venous catheter was inserted via an antecubital vein and a radial artery catheter was placed for continuous pressure monitoring. Arterial blood pressure was $180 / 105 \mathrm{~mm} \mathrm{Hg}$ and CVP was $0 \mathrm{~cm}$ 
$\mathrm{H}_{2} \mathrm{O}$ as measured on a column manometer demonstrating appropriate respiratory variation. CVP rose to $5 \mathrm{~cm} \mathrm{H} \mathrm{H}_{2} \mathrm{O}$ after a fluid bolus consisting of $500 \mathrm{ml}$ lactated Ringers solution and $300 \mathrm{ml}$ Hetastarch (Hespan).

With the patient in the left lateral decubitus position the L2-3 epidural space was cntered with an 18 gauge Crawford needle using a paramedian approach and the loss of resistance technique. There was no evidence of CSF flowing from the needle. A 20 gauge Deseret epidural catheter was passed $3 \mathrm{~cm}$ beyond the needle tip. The catheter was secured in place. Following a negative aspiration for CSF or blood, $3 \mathrm{ml}$ of 0.5 per cent bupivacaine (Abbott ${ }^{(D)}$ ) with freshly added $15 \mu \mathrm{g}$ epinephrine (final concentration $1 / 200,000$ ) was injected over 15 seconds. During this time the patient denied parethesias and did not cough or strain. Ninety seconds after injection, routine questioning regarding possible effects of the test dose elicited a response of numbress of her tongue and around her mouth. Using a needle, the patient felt no pin prick of her shoulders, neck, chin, cheeks, or forehead but her grasp was normal in the upper estremities bilaterally. Blood pressure dropped precipitously to $80 / 40$ $\mathrm{mmHg}$. Lactated Ringers solution $500 \mathrm{ml}$ and several intravenous doses of ephedrine (total $50 \mathrm{mg}$ ) were given over the next 15 minutes resulting in blood pressures of $100-110 / 60-80 \mathrm{mmHg}$ and heart rates of $90-100$ beats/minute. The patient received 100 per cent oxygen via mask immediately and remained completely responsive to verbal commands, denying dy spnoea throughout the entire episode, although her voice became very soft and hoarse after 3-5 minutes. Left ulerine displacement was maintained, with the legs elevated $15^{\circ}$. Centra] venous pressure was in the $0-2 \mathrm{~cm} \mathrm{H}_{2} \mathrm{O}$ range at this time. Foetal monitoring revealed a slight tachycardia. The patient was transported to the operating room for Caesarean-section. Sensory exam again revealed absence of sensation to pinprick to the level of all three sensory distributions of the trigeminal nerve. There was motor block of the lower extremities but voluntary respiration and grip strength were apparently intact.

The operation was performed without additional anaesthetic, while the patient remained comfortable throughout the procedure breathing 100 per cent oxygen spontaneously until delivery of the foetus, at which time $\mathrm{O}_{2}$ was discontinued. Apgar scores at one and five minutes were six and nine, respectively.

The patient's blood pressure returned to preanaesthetic levels approximately 60 minutes after the onset of the block and this was coincident with the receding of the sensory level to the T 6 dermatome. She regained full motor and sensory function approximately $2 \frac{1}{2}$ hours after initiation of the block. Aspiration of the catheter with a syringe prior to removal revealed clear spinal fluid.

Mother and infant did well with no further complications or sequelae. The patient was subsequently placed on oral antihypertensive medication for blood pressure control.

\section{Discussion}

Two unusual problems observed in this case are noteworthy. First was the development of a high sensory level of anaesthesia (cranial nerve $v$ ) without the usual findings of total spinal anaesthesia (restlessness, respiratory failure, loss of consciousness) as described in the literature, ${ }^{4-7}$ despite significant hypotension. Secondly, the test dose of local anaesthetic, bupivacaine $15 \mathrm{mg}$, given in this case is what most authors consider to be a safe subarachnoid dose, ${ }^{8,9}$ and has not, to our know. ledge, been reported to achieve this high a level of spinal cord blockade. Perhaps the combined effects of an elderly parturient, obesity, and superimposed pre-eclampsia add further to the already long list of controllable and uncontrollable factors influencing spinal anaesthesia? ${ }^{10-14}$ It is of concern when, as in this case, a relatively low dose causes precisely what one is trying to avoid.

Following an usual spinal block, a higher level of sensory than motor blockade of two segments is expected. However, this case report illustrates that a much wider differential of sensory vs motor blockade is possible. Careful evaluation of the patient, even under the most stressful situation should help to avoid iatrogenic complications. This patient might have bеen intubated unnecessarily because it is "proper" to protect the airway of the patient who has an unintentional total spinal. The definition of a "total spinal" may have to be modified in light of the present experience since there was sensory block to the fifth cranial nerve, but the cervical and perhaps also the thoracic segments were spared.

Epidural anaesthesia/analgesia has been shown 
to be a safe technique in patients with moderate to severe toxaemia of pregnancy and we favour this technique in our institution..$^{9,15-17}$ However, with the experience of this case in mind, we are approaching the test dose more cautiously. Since $7.5 \mathrm{mg}$ of bupivacaine in a hyperbaric solution has been demonstrated to produce a distinguishable block, ${ }^{18}$ a $10 \mathrm{mg}$ bupivacaine dose $(0.5$ per cent, 2 ml) with $15 \mu \mathrm{g}$ epinephrine may be an appropriate epidural test dose to detect an inadvertent subarachnoid or intravascular injection. We randomly sampled 10 ampules of 0.5 per cent bupivacaine (Abbott ${ }^{(5)}$ ) and found a specific gravity of 1.002 at $25^{\circ} \mathrm{C}$ (isobaric relative to "normal" CSF).

This report reinforces the doctrine that parturients require a smaller dose of local anaesthetic to block the spinal segments and further cautions the handling of the obese and hypertensive parturient. Furthermore, the question is raised as to whether there may be different physical characteristics of $\mathrm{CSF}$ in this patient population as compared to normal parturients.

\section{References}

1 Shnider SM, Levinson G. Obstetric anaesthesia. In Anaesthesia, R Miller, (ed). Churchill Livingston, $1981,1154$.

2 Moore DC. Regional Block, 4th ed. Springfield: Charles C Thomas Publisher, 1971, 353-6.

3 Hodgkinson R, Husain FJ. Epidural test dose in obstetrics. Anesth Analg 1980; 59: 811.

4 Bonica JJ. Principles and Practice of Obstetric Analgesia and Anesthesia. Philadephia: FA Davis Company, 1967, 718-20.

5 Dawkins CJM. An analysis of the complications of extradural and caudal block. Anaesthesia 1969; 24: 554-63.

6 Gillies IDS, Morgan M. Accidental total spinal analgesia with bupivacaine. Anaeșthesia 1973; 28: $441-5$.

7 Holdsworth JD, Roulston RG. An unusally high block following intrathecal bupivacaine. Anaesthe sia 1982; 37: 347-8.

8 Moore DC, Batra MS. The components of an effective test dose prior to epidural block. Anesthesiology 1981; 55: 693-6.

9 Gibbs CP. Anesthetic management of the high risk pregrant patient: Pre-eclampsia and diabetes. In New Anesthetic Agents, Devices and Monitoring
Techniques. TH Stanley and WC Pelty, (eds). Holland: Martinus Nishoff Publishers, 1983.

$10 \mathrm{Kerr} M G$, Scon $D B$, Samuel E. Studies of the inferior vena cava in late pregnancy. Br Mcd J 1964; I: $532-3$.

11 Russel IF. Intrathecal bupivacaine $0.5 \%$ for Caesarean section. Anaesthesia 1982; 37: 346-7.

12 Fagraeus $L$. Spread of epidural analgesia in carly pregnancy. Anesthesiology 1983; 58: 184-7.

13 Brown BK Jr. Anesthesia and the Obese Patient. Philadelphia: FA Davis Company, 1983, 77-9.

14 Land PC. Principles and Practice of Spinal Anesthesia. Springfield, Illinois: Charles C. Thomas Publishers, 1971, 97-120.

15 Joyce TH III, Loon $M$. Pre-eclampsia: Effect of albumin 25\% infusion. Anesthesiology 1981; 55: A313.

16 Joyce TH III, Debnath KS, Baker EA. Preeclampsia: Relationship of CVP and epidural anaesthesia. Anesthesiology 1979; 51: $\$ 297$ (abstract).

17 Katz J, Berumof $J$, Kadis $L B$. Anesthesia and Uncommon Diseases, 2nd edition. WB Saunders Co. , 1981, 89-90.

18 Moore $D C$. Bupivacaine compared with tetracaine for spinal anesthesia. Anesth Analg 1980; 59; 743-50.

Résumé

Nous rapportons un cas de rachi-anesthésie haute accidentelle chez une patiente de 40 ans, obèse, enceinie de 38 semaines et en ètat de pré-éclampsie.

Malgré la mise en place du cathéter épidural de façon apparemment très soignée, la dose-test de bupivacaïne 0.5 pour cent dans $3 \mathrm{ml}$ a produit des effets inattendus en bloquant la composante sensitive du cinquicme nerf crânien tous en épargnant les parties morrices des segments cervicaux et thuraciques. Un tel cas suggere que les doses-test de bupivacaine devraient être réduites spécialement chez les patientes obèses et pré-ćclamp. tiques. 